\title{
Understanding trophic relationships among Caribbean sea urchins
}

\author{
Ruber Rodríguez-Barreras ${ }^{1}$, Elvira Cuevas ${ }^{2,3}$, Nancy Cabanillas-Terán ${ }^{4} \&$ Benjamin Branoff ${ }^{2}$
}

1. University of Puerto Rico in Bayamón, Department of Biology, Industrial Minillas 170, Carr. 174, Bayamón, PR 00959-1919; ruber.rodriguez@upr.edu

2. Department of Biology, University of Puerto Rico, San Juan, Puerto Rico, 00931-3360; benjamin.branoff@upr.edu

3. Center for Applied Tropical Ecology and Conservation, University of Puerto Rico, PO Box 23332, San Juan, Puerto Rico, 00931-3332; epcuevas@gmail.com

4. Departamento de Sistemática y Ecología Acuática, El Colegio de la Frontera Sur, unidad Chetumal, Av. Centenario Km. 5.5, CP 77014, Chetumal, Quintana Roo, México; nanchamex@gmail.com

Received 03-VI-2015. C Corrected 20-I-2016. $\quad$ Accepted 25-II-2016.

\begin{abstract}
The species Echinometra lucunter, Echinometra viridis, Lytechinus variegatus, Tripneustes ventricosus, and Diadema antillarum are the most common sea urchins of littoral habitats in the Caribbean. T. ventricosus and L. variegatus are associated with seagrass beds, while the other three species usually inhabit hardground substrates. Food preferences of these species are well documented and they are commonly accepted as being primarily herbivorous-omnivorous; nevertheless, few of them have previously been characterized isotopically. We used this approach for assessing the isotopic characterization of five echinoids. We established the trophic position of two groups of co-occurring species and quantified the contribution of food resources in the diet of Echinometra lucunter, considered the most common sea urchin in the Caribbean region. The species $T$. ventricosus and $D$. antillarum showed the highest values of $\delta^{15} \mathrm{~N}$. Sea urchins exhibited similar values of $\delta^{13} \mathrm{C}$ varying from $-11.6 \pm 0.63$ to $-10.4 \pm 0.99 \%$. The echinoid $E$. lucunter displayed the lowest values of carbon, from $-15.40 \pm 0.76 \%$. Significant differences among species were found for $\delta^{15} \mathrm{~N}$ and $\delta^{13} \mathrm{C}$. Seaweed communities exhibited no differences among sites for overall $\delta^{15} \mathrm{~N}(\mathrm{~F}=1.300, \mathrm{df}=3, \mathrm{p}=0.301)$, but we found spatial differences for $\delta^{13} \mathrm{C}(\mathrm{F}=7.410, \mathrm{df}=3, \mathrm{p}=0.001)$. The ellipse-based metrics of niche width analysis found that the hardground biotope species (D. antillarum, E. lucunter, and E. viridis) did not overlap each other. Similar results were obtained for the co-occurring species of the seagrass biotope; however, the distance between these species was closer than that of the hardground biotope species. The Bayesian mixing models run for E. lucunter at all four localities found differences in food resources contribution. The algae D. menstrualis, C. crassa and B. triquetrum dominated in CGD; whereas C. nitens, Gracilaria spp., and D. caribaea represented the main contributor algae to the diet of E. lucunter at LQY. In Culebra Island, no dominance of any particular algae was detected in TMD, where six of the eight species exhibited a similar contribution. Similarities in $\delta^{15} \mathrm{~N}$ between $D$. antillarum and T. ventricosus may hint towards a similar trophic level for these species, although T. ventricosus is widely accepted as an omnivore, while $D$. antillarum is considered a generalist herbivore. The lack of overlap among species in the two biotopes seems to indicate a resource partitioning strategy to avoid niche competition among co-occurring species. Rev. Biol. Trop. 64 (2): 837-848. Epub 2016 June 01.
\end{abstract}

Key words: stable isotopes, trophic ecology, Bayesian mixing models, sea urchins, Puerto Rico.

The sea urchins Echinometra lucunter (Linnaeus, 1758), Echinometra viridis A. Agassiz, 1863, Lytechinus variegatus (Lamarck, 1816), Tripneustes ventricosus (Lamarck, 1816), and Diadema antillarum Philippi, 1845, are the most common littoral echinoids in the Caribbean. Two of them, T. ventricosus and L. variegatus are associated with seagrass beds; whereas the other three generally inhabit hardground biotopes (Hendler, Miller, Pawson, $\&$ Kier, 1995). Sea urchins have primarily have been classified as generalist herbivores, but some are considered facultative omnivorous (McPherson, 1969; Karlson, 1983; Tertschnig, 1989; Mahon \& Parker, 1999). Understanding complex trophic relationships is essential, 
especially in marine ecosystems, which host a variety of species that occupy apparently similar trophic positions (McCutchan, Lewis, Kendall, \& McGrath, 2003; Phillips, 2012). Co-occurring species generally coexist due to differences in feeding behavior and internal assimilation mechanisms (Wolf, Scott, \& Martínez del Río, 2009). The presence of two or more species in the same area may be possible through the existence of resource partitioning, which serves to limit niche competition among sea urchins (Vanderklift, Kendrick, \& Smith, 2006; Cabanillas-Terán, Loor-andrade, Rodríguez-Barreras, \& Cortés, 2016).

Biological processes responsible for carbon and nitrogen movement in and out the ocean are critical in determining the natural abundance of these two elements in marine ecosystems (Nixon et al., 1996). However, there is a high degree of spatial variability in coastal marine systems, mainly in nearshore and continental shelf waters due to biotic and abiotic factors (Van Dover, Grassle, Fry, Garrit, \& Starczak, 1992). Analysis of trophic relationships using stable isotopes is usually more complex, as primary producers and consumers are part of a complex trophic system in which changes in primary producers affect the isotopic signatures of herbivores (Fry \& Sherr, 1984; Peterson, Howarth, \& Garritt, 1985). For this reason, stable isotope studies have become a fundamental tool for assessing trophic niche interactions (DeNiro \& Epstein, 1981; Caut, Angulo, \& Courchhamp, 2008; Parnell, Inger, Bearhop, \& Jackson 2010; Boecklen, Yarnes, Cook, \& James, 2011, Rodríguez-Barreras, Cuevas, Cabanillas-Terán, \& Sabat, 2015).

Stable isotope analyses on dietary reconstructions rely on tissue signatures that provide valuable information on trophic level and potential food source choice in the diet of a given organism (Hobson \& Sease, 1998; McCutchan et al., 2003; Vanderklift \& Ponsard, 2003; Caraveo-Patiño \& Soto, 2005). Thus, carbon and nitrogen stable isotopes have been used to elucidate upon food habits (Peterson \& Fry, 1987), including the source and transformation of ingested organic matter (Peterson, Howarth,
\& Garritt, 1985), as well as on nutrient migration within food webs, trophic positioning of organisms, and their contribution to each trophic level (Vander-Zanden \& Rasmussen, 1996). Additionally, these analyses have provided evidence for high densities of individuals of different species occupying the same trophic position in the same ecosystem (Vanderklift et al., 2006). Mathematical algorithms have developed to estimate the contribution of each food resource to the consumer, providing valuable information towards their hierarchical contribution (Solomon et al., 2011). Known as mixing models, these routines have been used extensively as powerful tools in trophic studies (Semmens, Moore, \& Ward, 2009; Phillips, 2012). Mixing models have clarified important aspects of diet plasticity, differential assimilation of resources, association with biosynthetic pathways, and ecological consequences among others (Villinski, Hayes, Villinski, Brassell, \& Raff, 2004; Tomas, Alvarez-Cascos, Turon, \& Romero, 2006; Wing, McLeod, Clark, \& Frew, 2008). Furthermore, the most recent Bayesian ellipses techniques have allowed stronger comparisons of isotopic niches across communities (Jackson, Inger, Parnell, \& Bearhop, 2011).

Sea urchin digestive processes may be considered among the best studied among marine invertebrates (Lewis, 1964; Trenzado et al., 2012; Lawrence, Lawrence, \& Watts 2013). For instance, Klinger, Hsieh, Pangallo, Chen, \& Lawrence (1986) and Hawkins (1981) studied assimilative processes in L. variegatus and D. antillarum, respectively. Additionally, there are several studies of echinoids using a stable isotope approach (Minagawa \& Wada, 1984; Rodríguez, 2003; Tomas et al., 2006; Vanderklif et al., 2006; Wing et al., 2008; Prado, Alcoverro \& Romero, 2010; Wangensteen et al., 2011). Specifically, Cabanillas-Terán (2009) quantified its food resources contribution in the diet of Diadema africanum, formerly Diadema aff. antillarum; whereas Prado, Carmichael, Watts, Cebria \& Heck, (2012) experimentally determined the trophic enrichment factor for the green echinoid Lytechinus variegatus. Despite this, there is no other available information for 
sea urchins in the Caribbean related to their trophic interactions or diet assimilation of food resources using stable isotopes. We used this approach for assessing the isotopic characterization of five echinoids. We established the trophic position of two groups of co-occurring species and quantified the contribution of food resources in the diet of Echinometra lucunter, considered one of the most common sea urchin in the Caribbean region.

\section{MATERIAL AND METHODS}

Study site and data collection: Surveys were conducted in October of 2013 at four reef crests of the Puerto Rico Archipelago. Two sites were located on the Northeastern coast of Puerto Rico, with the other two located off the island of Culebra (Fig. 1). Sites were Cerro Gordo (CGD: $18^{\circ} 16^{\prime} 51.40^{\prime \prime} \mathrm{N}-65^{\circ} 17^{\prime} 12.21^{\prime \prime}$ W), Luquillo (LQY: 18²3'18.46” N - 654'5.52" W), Tamarindo Bay (TMD: $18^{\circ} 18^{\prime} 55.29^{\prime \prime} \mathrm{N}-65^{\circ} 19^{\prime} 5.82^{\prime}$ ' W), and Melones (MLN: $18^{\circ} 18^{\prime} 15.70^{\prime \prime} \mathrm{N}-65^{\circ} 18^{\prime} 42.27^{\prime \prime}$ W). All sites are shallow-water fringing reefs between $1-2 \mathrm{~m}$ in depth. Culebra Island has no rivers, precipitation average is low, and volcanic and intrusive rocks, with some limestone deposits (U.S.G.S., 1996), characterize the substrate. The sites CGD and LQY are composed of carbonate rocks (Rodríguez-Barreras, Pérez, Williams, Mercado-Molina, \& Sabat, 2014).

We collected five adults of the species Diadema antillarum, Echinometra viridis,
Lytechinus variegatus, and Tripneustes ventricosus from LQY. Additionally, five individuals of Echinometra lucunter were collected from all four localities (Fig. 1). The genus Echinometra and $D$. antillarum were collected in hardground biotopes (fringing reef), whereas L. variegatus and $T$. ventricosus were gathered in a backreef lagoon biotope covered by seagrass meadows. Sample sizes were based on previous studies (Rodríguez, 2003; Tomas et al., 2006; Wing et al., 2008; Cabanillas-Terán, 2009). Thus, we collected samples of all seaweed species within a $5 \mathrm{~m}$ radius from collecting sites associated only with E. lucunter. All organisms, including algae and sea urchins, were preserved in a dry-ice container and transported to the laboratory for later analyses. We identified twenty algae up to the lowest possible taxonomic level (Littler \& Littler, 2000). The species identified were Amphiroa fragilissima, Acanthophora spicifera, Bryothamnion triquetrum, Caulerpa racemosa, Ceramium nitens, Chaetomorpha crassa, Cladophora vagabunda, Dasya antillarum, Dictyota caribaea, Dictyota menstrualis, Gelidiella acerosa, Dichotomaria obtusata, Galaxaura rugosa, Gracilaria spp., Halimeda scabra, Hypnea valentiae, Jania adhaerens, Padina boergesenii, Palisada perforata, and Tricleocarpa fragilis.

Sample analysis: Carbon and nitrogen were measured from the muscle of the Aristotle's lantern (echinoids), and from bulk tissues (algae). Once defrosted, calcified algae

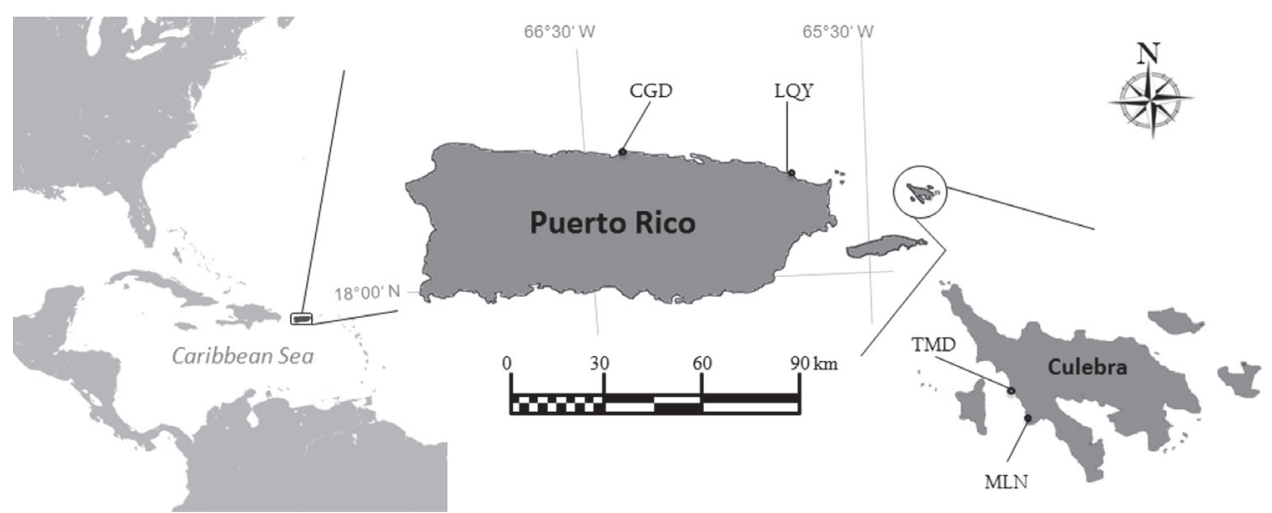

Fig. 1. Study area and sampling sites in Puerto Rico. Cerro Gordo (CGD), Luquillo (LQY), Tamarindo (TMD), and Melones (MLN). 
samples were washed twice with diluted solutions of $\mathrm{HCl}$ at $12 \%$ and $10 \%$ respectively, to remove any excess carbonate (Bunn, Loneragan, \& Kempster, 1995). Samples were rinsed with distilled water and dried in an air circulating Shel Lab Oven at $60{ }^{\circ} \mathrm{C}$ for 48 hours. After drying, samples were ground to a fine powder using a frequency grinder. Because the acid-wash procedure alters $\delta^{15} \mathrm{~N}$ results, calcified algae required two samples each: one acid washed for $\delta^{13} \mathrm{C}$ and one without acid-wash for $\delta^{15} \mathrm{~N}$. Samples of 0.9-1.3 mg for sea urchin tissue, and 3.9-4.4 mg for algae samples were stored in tin capsules. Measurements of stable isotope ratios were obtained in a continuous flow isotope ratio mass spectrometer at the Laboratory of Stable Isotope Ecology in Tropical Ecosystems, at the University of Miami. Results for $\delta^{13} \mathrm{C}$ and $\delta^{15} \mathrm{~N}$ were expressed as parts per thousand (\%) differences from the standard $(\delta)$ : Vienna Pee Dee Belemnite (vPDB) for $\delta^{13} \mathrm{C}$, and atmospheric $\mathrm{N}_{2}$ for $\delta^{15} \mathrm{~N}$. Carbon and nitrogen samples were analyzed in a dual isotope mode. Ratios were then used to complete equation 1 , where $\mathrm{R}_{\text {sample }}$ and $\mathrm{R}_{\text {standard }}$ are the values of ${ }^{13} \mathrm{C} /{ }^{12} \mathrm{C}$ or ${ }^{15} \mathrm{~N} /{ }^{14} \mathrm{~N}$ in the sample and the standard, respectively.

$$
X(\%)=\left[\left(\frac{\mathrm{R} \text { sample }}{\mathrm{R} \text { standard }}\right)-1\right] \times 1000 \quad \text { Eq. } 1
$$

For E. lucunter only, we run a Bayesian mixing model and SIBER using SIAR 4.2 (Stable Isotopes Analysis in R) package in the repository Comprehensive R Archive Network (Parnell \& Jackson, 2013). This package uses organism isotopic data to fit a model to their dietary habits based upon a Gaussian likelihood and a mixture Dirichlet-distributed prior on the mean. Models were run with 100000 iterations and a burn in of 50000. This routine takes bivariate isotope data in $\mathrm{x}$ and $\mathrm{y}$, and returns the posterior draws for the metric SEA.B (Standard Ellipse Area. Bayesian) for each group. We selected eight algae at every site, except in LQY, where we used seven species, and the percent of contribution of each algae species to the measured isotopic signatures was determined. We run SIBER (Stable Isotope Bayesian Ellipses) to calculate ellipse based metrics of niche width, and determined the existence of any overlap among co-occurring species. SIBER was run twice, once for the hardground biotope (D. antillarum, E. lucunter, and $E$. viridis), and again for the seagrass biotope ( $T$. ventricosus, and L. variegatus). We considered an isotopic fractionation across trophic levels of $3.4 \%$ for $\delta^{15} \mathrm{~N}$ and $1.0 \%$ for $\delta^{13} \mathrm{C}$ (Vander-Zanden \& Rasmussen, 2001; Post, 2002; Wing et al., 2008).

Normality and homogeneity of variance were tested by running the KolmogorovSmirnov and Cochran tests, respectively (Zar, 2010). Nitrogen data followed the premises of parametric analysis, but the carbon data required a square-root transformation (Box $\&$ Cox, 1964). We ran a one-way ANOVA for comparisons of $\delta^{15} \mathrm{~N}$ and $\delta^{13} \mathrm{C}$ among sea urchins, and a posteriori Tukey-HSD test was used for multiple comparisons of the means. In addition, we ran a One-way ANOVA to analyze spatial differences among isotopic signals of carbon and nitrogen on E. lucunter and the seaweed communities. Statistics were performed with $\alpha<0.05$ in R-2.9.13 (R Development Core Team, 2014).

\section{RESULTS}

The $\delta^{15} \mathrm{~N}$ signal for the five studied echinoids of hardground biotopes varied from 5.77 $\pm 0.25[$ mean $\pm \mathrm{SD}$ ] to $8.22 \pm 0.36 \%$; whereas the species collected on seagrass biotopes showed values of nitrogen from $6.09 \pm 0.79$ to $8.02 \pm 0.36 \%$ (Fig. 2A). The species T. ventricosus and $D$. antillarum showed the highest values of $\delta^{15} \mathrm{~N}$. Sea urchins exhibited similar values of $\delta^{13} \mathrm{C}$ varying from $-11.6 \pm 0.63$ to $-10.4 \pm 0.99 \%$. The echinoid E. lucunter displayed the lowest values of carbon, from $-15.40 \pm 0.76 \%$ o (Fig. 2B). Significant differences among species were found for $\delta^{15} \mathrm{~N}$ and $\delta^{13} \mathrm{C}$ (Table 1). A posteriori analysis displayed differences in $\delta^{15} \mathrm{~N}$ between the group formed by E. lucunter, E. viridis and L. variegatus and the upper group formed by $D$. antillarum and 


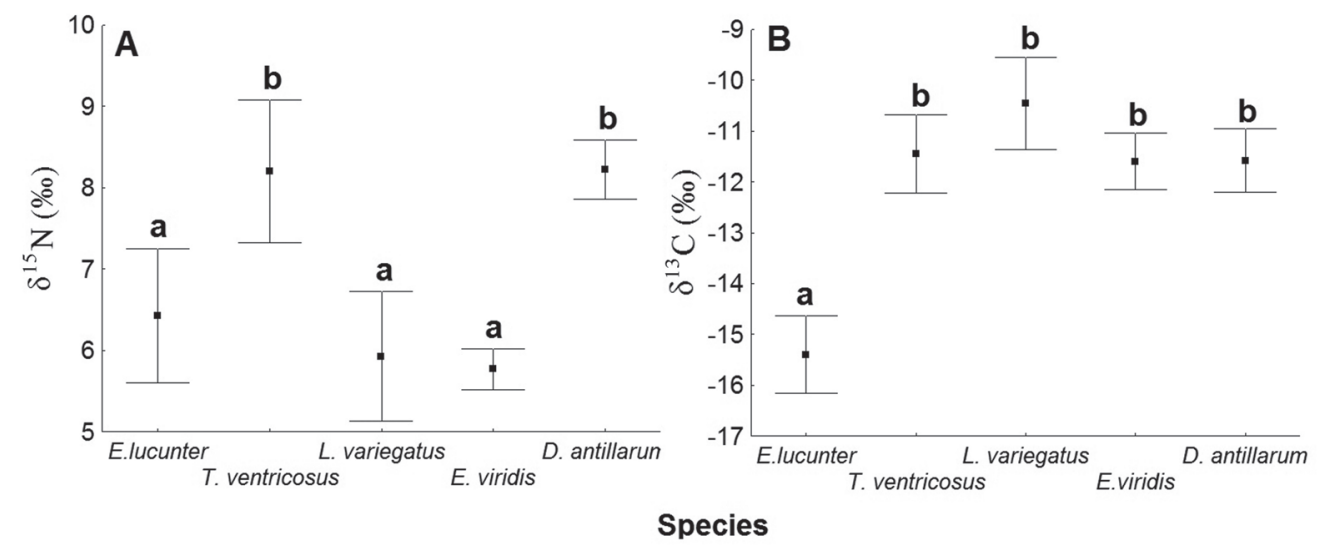

Fig. 2. $\delta^{15} \mathrm{~N}(\mathrm{~A})$ and $\delta^{13} \mathrm{C}$ (B) values of five echinoids of Puerto Rico (mean \pm S.D.).

TABLE 1

Analysis of variance of the isotopic signals of Carbon and Nitrogen among the five sea urchin species

\begin{tabular}{lcccccc} 
& \multicolumn{4}{c}{$\delta^{13} \mathrm{C}$} & \multicolumn{3}{c}{$\delta^{15} \mathrm{~N}$} \\
& df & F & P & df & F & P \\
Species & 4 & 33.08 & $<0.001 *$ & 4 & 15.04 & $<0.001 *$ \\
& & SS & MS & & SS & MS \\
Error & 20 & 11.35 & 0.568 & 20 & 9.68 & 0.48 \\
\hline
\end{tabular}

* significance.

T. ventricosus $(\mathrm{p}<0.001$, Fig $2 \mathrm{~A})$. Whereas differences in terms of $\delta^{13} \mathrm{C}$ were found in $E$. lucunter with respect to the other four species $(\mathrm{p}<0.001$, Fig 2B). We found no differences in $\delta^{15} \mathrm{~N}$ signal of $E$. lucunter among sites, but we did find spatial differences in $\delta^{13} \mathrm{C}(\mathrm{F}=7.410$, $\mathrm{df}=3, \mathrm{p}=0.001)$. Those spatial differences were between the sites CGD and TMD ( $\mathrm{p}=$ $0.001)$, and between CGD and LQY $(p=0.020)$.

The overall isotopic signal of $\delta^{15} \mathrm{~N}$ for seaweed communities associated with hardground biotopes varied from $1.7 \pm 0.56$ (MLN) to 3.3 $\pm 1.24 \%$ (CGD), whereas the $\delta^{13} \mathrm{C}$ varied from $-15.2 \pm 2.51$ (LQY) to $-13.5 \pm 3.58 \%$ (CGD). The lowest nitrogen isotopic signals were obtained in TMD (D. menstrualis: $1.1 \%$ ) and MLN (G. rugosa: $1.1 \%$ ); while the highest value was recorded in CGD (B. triquetrum: $4.8 \%$ ). Both maximum (J. adhaerens: $-8.1 \%$ ) and minimum (D. menstrualis: $-8.7 \%$ ) $\delta^{13} \mathrm{C}$ values were recorded in CGD (Fig. 3). No differences among sites were detected for overall $\delta^{15} \mathrm{~N}(\mathrm{~F}=1.300, \mathrm{df}=3, \mathrm{p}=0.301)$, but we found spatial differences for $\delta^{13} \mathrm{C}(\mathrm{F}=7.410$, $\mathrm{df}=$ $3, p=0.001)$. A posteriori analysis displayed differences between CGD with respect to the other three sites $(p<0.05)$.

The ellipse-based metrics of niche width analysis -restricted to one locality- found that the hardground biotope species (D. antillarum, E. lucunter, and E. viridis) did not overlap each other (Fig 4A). Similar results were obtained for the co-occurring species of the seagrass biotope; however, the distance between these species was closer than that of the hardground biotope species (Fig 4B). The Bayesian mixing models run for E. lucunter at all four localities found differences in food resources contribution. For instance, the algae $D$. menstrualis, $C$. crassa and B. triquetrum dominated in CGD; whereas C. nitens, Gracilaria spp., and D. caribaea represented the main algae species to the diet of E. lucunter at LQY (Table 2). In Culebra Island, no dominance of any particular algae was detected in TMD, where six of the eight species exhibited a similar contribution (Table 2). Although MLN displayed a similar low dominance of species as that of TMD, two algae remained with a mean contribution over $15 \%$ : Dichotomaria obtusata and Dasya antillarum. 


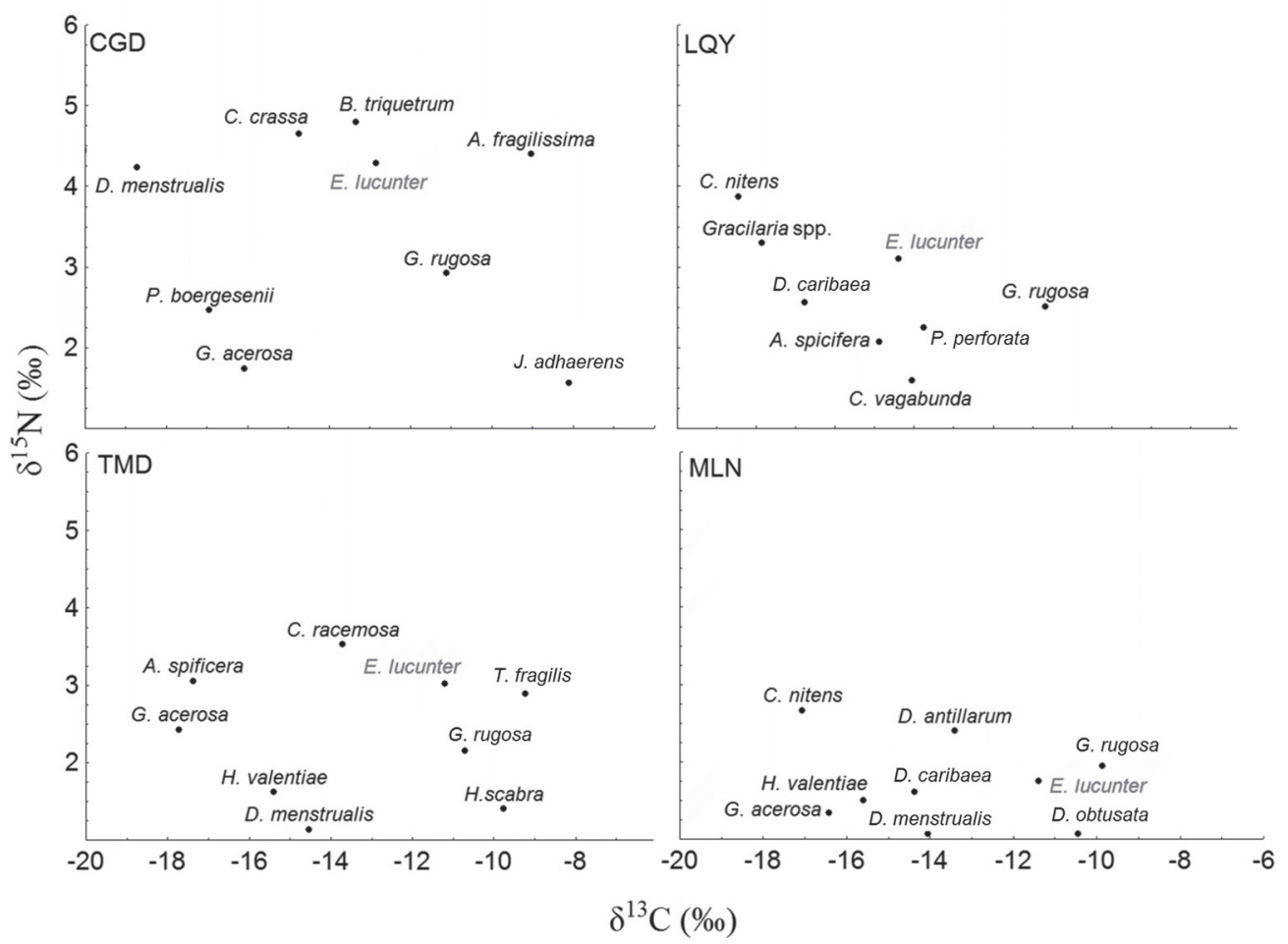

Fig. 3. Isotopic signal of carbon and nitrogen of the potential food resources of the sea urchin Echinometra lucunter (in red) of hardground biotopes at four localities of Puerto Rico Archipelago. Correction factors used for the mixture (echinoid) were $3.4 \%$ for $\delta^{15} \mathrm{~N}$ and $1.0 \%$ for $\delta^{13} \mathrm{C}$. The $\delta^{15} \mathrm{~N}$ scale differs between TMD/MLN and CGD/LQY. The sample size was five individuals per species.

TABLE 2

Average percentage contribution of seaweeds to the diet of the sea urchin E. lucunter at four sites of Puerto Rico Archipelago

\begin{tabular}{lccccccc}
\multicolumn{1}{c}{ CGD species } & mean & Credibility min & Interval max & \multicolumn{1}{c}{ LQY species } & mean & Credibility min Interval max \\
D. menstrualis & 0.24 & 0.08 & 0.41 & C. nitens & 0.22 & 0.03 & 0.23 \\
C. crassa & 0.21 & 0.06 & 0.40 & Gracilaria spp. & 0.20 & 0.01 & 0.21 \\
B. triquetrum & 0.20 & 0.01 & 0.38 & D. caribaea & 0.17 & 0 & 0.21 \\
P. boergesenii & 0.11 & 0 & 0.24 & A. spicifera & 0.12 & 0 & 0.03 \\
A. fragilissima & 0.07 & 0 & 0.16 & P. perforata & 0.11 & 0 & 0.03 \\
G. acerosa & 0.07 & 0 & 0.19 & C. vagabunda & 0.11 & 0 & 0.03 \\
G. rugosa & 0.07 & 0 & 0.18 & G. rugosa & 0.07 & 0 & 0.02 \\
J. adhaerens & 0.04 & 0 & 0.10 & & & & \\
TMD species & mean & Credibility min & Interval max & MLN species & mean & Credibility min Interval max \\
H. scabra & 0.16 & 0.01 & 0.28 & D. obtusata & 0.18 & 0.05 & 0.30 \\
G. rugosa & 0.14 & 0.01 & 0.26 & D. antillarum & 0.15 & 0.01 & 0.28 \\
D. menstrualis & 0.14 & 0.001 & 0.28 & G. rugosa & 0.14 & 0.01 & 0.26 \\
H. valentiae & 0.14 & 0 & 0.27 & D. caribaea & 0.12 & 0 & 0.23 \\
T. fragilis & 0.14 & 0.001 & 0.26 & C. nitens & 0.12 & 0.004 & 0.22 \\
G. acerosa & 0.13 & 0.002 & 0.25 & D. menstrualis & 0.11 & 0 & 0.23 \\
A. spicifera & 0.09 & 0 & 0.20 & H. valentiae & 0.10 & 0 & 0.22 \\
C. racemosa & 0.06 & 0 & 0.17 & G. acerosa & 0.09 & 0 & 0.20 \\
\hline
\end{tabular}

Sites are Cerro Gordo (CGD), Luquillo (LQY), Tamarindo (TMD), and Melones (MLN). 


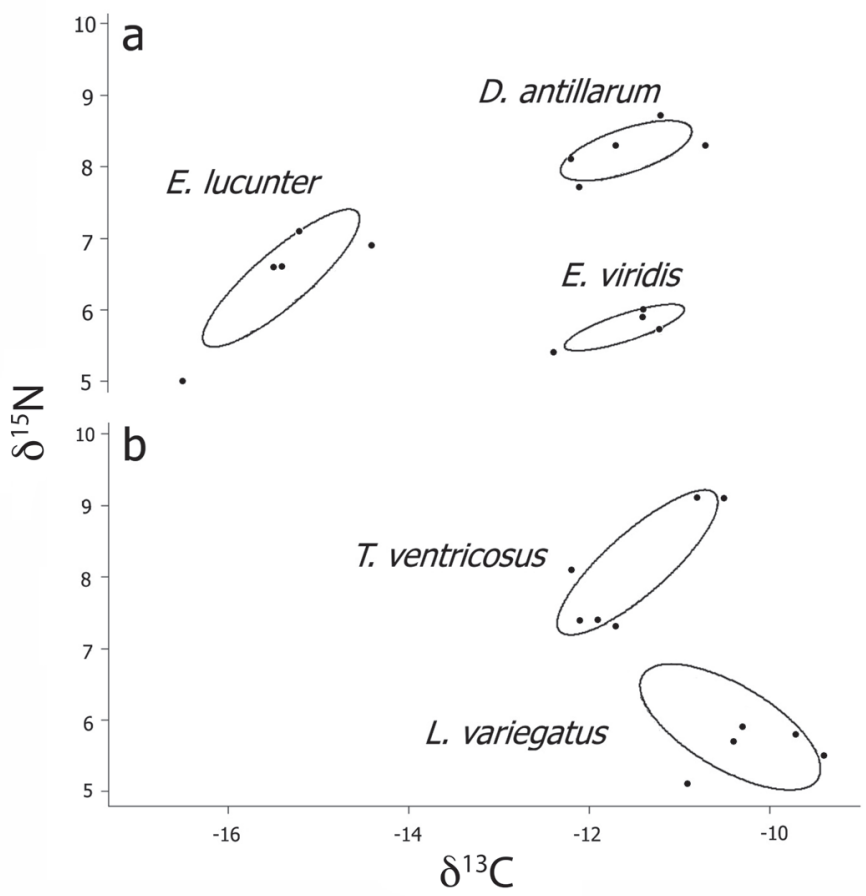

Fig. 4. Results of the ellipses based metrics of niche width for two echinoids groups based on habitat preferences. A: represents the three species inhabit in hardgrounds whereas. B: represents the species of seagrass meadows. Circles represent the potential niche of each species.

\section{DISCUSSION}

There is often a high degree of spatial variability in shallow-water ecosystems. Both nitrogen and carbon elemental concentrations may vary due to abiotic and biotic factors, including atmospheric deposition, volatilization, microbial processing, terrestrial runoff, etc. (Van-Dover et al., 1992; Nixon et al., 1996). Anthropogenic enrichment may alter marine benthic food webs, increasing the ratios of heavy isotopes in primary producers (McGlathery, 2001; Tewfik, Rasmussen, \& McCann, 2005). In fact, the presence of elevated values of $\delta^{15} \mathrm{~N}$ has been shown to be related with local $\mathrm{NO}_{3}$ enrichment (Clark \& Wilcock, 2000; Cloern, 2001). In general, our seaweed communities exhibited no spatial differences in nitrogen, which indicates a relative homogeneity in $\delta^{15} \mathrm{~N}$ among sites. This is probably due to their geographical proximity. In contrast, spatial differences among seaweed communities in terms of $\delta^{13} \mathrm{C}$ might be related to community composition, metabolic species-specific characteristics, or to local geomorphologic features. The CGD site exhibited differences with respect to the other three sites. This difference may be linked to the existence of a mangrove lagoon canal located approximately $200 \mathrm{~m}$ away. This is important because mangrove systems provide nutrient inputs, mainly carbon, to nearshore waters (Zieman, Macko, \& Mills, 1984; Rezende, Lacerda, Ovall, Silva \& Martinelli, 1990).

Food resources leave tracks within consumers throughout food web (Phillips, 2012), and usually one or two sources may contribute $50 \%$ or more of the diet of a given consumer (Rodríguez, 2003; Tomas et al., 2006). Mixing models indicated spatial differences among sites in the composition of algal food assimilated by the sea urchin E. lucunter. No single algal species exhibited high dominance in the diet of this sea urchin in TMD and MLN. 
However, some algae reported mean dietary contribution greater than $20 \%$ in CGD and LQY, but never as high as 30 or $40 \%$ for a single species. These results contrast with other studies where some algae species may compromise up to $60 \%$ of urchin diets (Rodríguez, 2003; Prado et al., 2010; Cabanillas-Terán et al., 2016). Although contrasting, trophic plasticity is widespread in nature, and may explain the apparent difference in urchin diets (Pinnegar \& Polunin, 2000; Wing et al., 2008).

The existence of spatial differences reflects the feeding plasticity of E. lucunter and its ability to use a wide range of food resources. The fact that the Culebra sites showed a lower algal contribution in sea urchin diets might be related to local seaweed assemblages than to feeding preferences. A generalist feeding behavior is very common in sea urchins, and E. lucunter is not an exception (Hendler et al., 1995; Lawrence et al., 2013). The lack of data on seaweed communities did not allow us to quantify algal abundances or establish a relationship between seaweed abundance and its magnitude of contribution to the diet of E. lucunter. We do not suspect that the reason why the sea urchin diet is distributed among so many algae types is due simply to the low species number (8) included in this two-isotope mixing model. Previous studies have stated that those resources, whose isotopic signals most resemble those of the sea urchin, are in general the most important contributors to the diet of a given species (Szepanski, Ben-David, \& Van Ballenberghe, 1999; Ben-David \& Shell, 2001). There is a possibility that $E$. lucunter may be selectively feeding on a few algal species, and different combinations could produce the same isotopic signal; nevertheless, further studies will need to focus on isotopic markers to prove this diversity in the diet of E. lucunter.

Co-occurring species coexist due to differences in feeding behavior and internal assimilation mechanisms (Vanderklift et al., 2006; Wolf et al., 2009). Differences in $\delta^{13} \mathrm{C}$ detected among the five echinoids of two different biotopes may suggest that $E$. lucunter uses different sources of carbon with respect to the other two species of the hardground biotope (Fig. 4A), whereas D. antillarum and E. viridis coincided in terms of $\delta^{13} \mathrm{C}$. However, the lack of overlap between both species suggests the use of different sources of nitrogen and a higher trophic position for $D$. antillarum, which may be more related to an omnivorous strategy. A similar case of niche partitioning was discussed for three sympatric sea urchins in Australia (Vanderklift et al., 2006).

The other two co-occurring species within seagrass bed habitats also exhibited no niche overlap (Fig 4B). However, both echinoids coincided in terms of $\delta^{13} \mathrm{C}$, which may indicate the use of similar food resources. A higher trophic position of $T$. ventricosus, however, could indicate the use of other food items, $\delta^{15} \mathrm{~N}$-enriched. These two species are common dwellers of seagrass meadows. There, $T$. ventricosus usually grazes on Thalassia testudinum leaves, but also ingests small invertebrates; whereas $L$. variegatus feeds on T. testudinum, detritus, and some epiphytes (Keller, 1983; Barrios \& Reyes, 2009). The isotopic signal of $\delta^{15} \mathrm{~N}$ for $T$. ventricosus was also in consonance with its omnivorous behavior, and relatively far from the isotopic signature of $T$. testudinum leaves (unpublished data). A stomach content analysis on $T$. ventricosus found bryozoans, ascidians, and hydrozoans (Barrios \& Reyes, 2009). Thus, $\delta^{15} \mathrm{~N}$ in T. ventricosus was similar with the isotopic signal of the omnivorous sea urchins Centrostephanus tenuispinus, Phyllacanthus irregularis, Strongylocentrotus pallidus and Arbacia lixula (Vanderklift et al., 2006; Wangensteen et al., 2011). Nevertheless, the Mediterranean echinoid Paracentrotus lividus, considered an important grazer of the vascular plant, Posidonia oceanica, reported values of nitrogen between 9-10\%. This particularly high value of $\delta^{15} \mathrm{~N}$, which could be considered too high for a grazer, was due to the existence of an epiphyte community growing on Posidonia leaves that covers part of the carbon and nitrogen requirements in the diet of the echinoid P. lividus (Tomas et al., 2006). Therefore, the ingestion of small invertebrates by $T$. ventricosus may be not an accidental 
intake, but an important source of nitrogen that gives this sea urchin a higher trophic position in seagrass biotopes.

The high $\delta^{15} \mathrm{~N}$ values found in $D$. antillarum contrasts with its feeding preferences (Rodríguez-Barreras et al., 2015). The sea urchin D. antillarum has considered primarily a generalist herbivore that feeds principally upon algae (Hendler et al., 1995). However, this sea urchin also ingests invertebrates (Serafy, 1979). Stomach content analyses have revealed the presence of sponges, hydroids, bryozoans, nematodes, rotifers, gastropods, bivalves, and copepods. These invertebrates may represent up to $32 \%$ of the gut species-richness index (Herrera-López et al, 2004; Hernández et al., 2006). Indeed, some authors proposed Diade$m a$ as an omnivore (Rotjand \& Lewis, 2008), but the idea has met resistance. The presence of invertebrates within the Diadema diet has considered a non-selective behavior, due only to accidental scraping off, but never an important component of the sea urchin diet. The high value of $\delta^{15} \mathrm{~N}$ displayed for $D$. antillarum, similar to $T$. ventricosus, suggests that both sea urchins occupy similar trophic levels in their respective habitats, and support an omnivorous feeding behavior for $D$. antillarum. However, this tentative statement requires further studies to determine the main food resources, including invertebrates.

To conclude, a Bayesian mixing model indicates feeding plasticity of E. lucunter, using multiple food algal resources depending on local availability. Similarities in $\delta^{15} \mathrm{~N}$ between $D$. antillarum and T. ventricosus may hint at a similar trophic level for both species (omnivorous) which is widely accepted for $T$. ventricosus, but not for D. antillarum, often considered a generalist herbivore species. Thus, the lack of overlap among species in the two biotopes seems to indicate a resource partitioning strategy to avoid niche competition among co-occurring species.

\section{ACKNOWLEDGMENTS}

Special thanks to the Center for Applied Tropical Ecology and Conservation (CATEC) for their economic and logistic support. The first author also wants to thank to Donald Phillips, Catalina Dávila, Alain Durán, and Owen Wangensteen for their valuable information and comments to improve this manuscript.

\section{RESUMEN}

Relaciones tróficas entre los erizos de mar Caribe. Las especies Echinometra lucunter, Echinometra viridis, Lytechinus variegatus, Tripneustes ventricosus, and Diadema antillarum son los erizos de mar más comunes en los hábitat litorales del Caribe. Los erizos de mar $T$. ventricosus y $L$. variegatus habitan generalmente los pastos marinos mientras que las otras tres especies se encuentran asociadas a sustratos rocosos. Los hábitos alimentarios de estas especies han sido bien documentados y son reconocidas como herbívoros - omnívoros; sin embargo, pocas de estas especies han sido caracterizadas isotópicamente. Utilizamos los isótopos estables para caracterizar estas cinco especies de erizos y establecer las posiciones tróficas para las especies que cohabitan los mismos ecosistemas. También cuantificamos la contribución de los recursos alimentarios para E. lucunter. Los erizos $T$. ventricosus y $D$. antillarum mostraron los mayores valores de $\delta^{15} \mathrm{~N}$ y valores similares de $\delta^{13} \mathrm{C}$ que variaron desde $-11.6 \pm 0.63 \mathrm{a}$ $-10.4 \pm 0.99 \%$; donde el erizo $E$. lucunter mostró los valores más negativos con $-15.40 \pm 0.76 \%$. Las comunidades de algas no mostraron diferencias en valores promedio de $\delta^{15} \mathrm{~N}(\mathrm{~F}=1.300, \mathrm{df}=3, \mathrm{p}=0.301)$, pero sí mostraron variaciones en los valores de $\delta^{13} \mathrm{C}(\mathrm{F}=7.410, \mathrm{df}=3, \mathrm{p}=0.001)$. Los estudios de amplitud de elipses de nicho determinaron que las especies de los biotopos rocosos (D. antillarum, $E$. lucunter y E. viridis) no mostraron solapamiento de nicho. Similar resultado también se encontró en las especies de erizos que habitan en los pastos marinos. Sin embargo, la distancia entre estas dos especies fue menor respecto a la distancia entre las especies de erizos que habitan en los sustratos rocosos. Nuestros resultados muestran que las especies que habitan en los pastos marinos mostraron valores más elevados de $\delta^{13} \mathrm{C}$ en comparación con las especies de los sustratos rocosos. No se encontraron diferencias espaciales para $E$. lucunter en $\delta^{15} \mathrm{~N}$, pero sí en $\delta^{13} \mathrm{C}$. Los modelos de mezcla bayesianos demuestran la plasticidad alimentaria de E. lucunter, especie capaz de utilizar múltiples recursos algales dependiendo de la disponibilidad por 
sitio. Semejanzas en $\delta^{15} \mathrm{~N}$ entre $D$. antillarum y $T$. ventricosus parecen indicar similitudes tróficas entre ambas especies. Si bien T. ventricosus es reconocido como omnívoro, D. antillarum siempre ha sido considerado un herbívoro generalista. Finalmente, la falta de solapamiento entre las especies en los dos biotopos parece indicar una estrategia de partición de recursos para evitar la competencia de nicho entre especies concurrentes.

Palabras clave: isótopos estables, ecología trófica, modelos de mezcla, erizos de mar, Puerto Rico.

\section{REFERENCES}

Barrios, J., \& Reyes, J. (2009). Hábitos alimenticios de Tripneustes ventricosus (Lamarck 1816) (Echinodermata, Echinoidea) en isla la Tortuga, Venezuela. Recursos Marinos Acuiferos, 2, 583-589.

Ben-David, M., \& Schell, D. M. (2001). Mixing models in analyses of diet using multiple stable isotopes: a response. Oecologia, 127, 180-184.

Boecklen, W. J., Yarnes, C. T., Cook, B. A., \& James, A. C. (2011). On the use of stable isotopes in trophic ecology. Annual Review in Ecology and Systematics, 42, 411-440.

Box, G. E. P., \& Cox, D. R. (1964). An analysis of transformations (with discussion). Journal of the Royal Statistical Society B., 26, 211-252.

Bunn, S. E., Loneragan, N. R., \& Kempster, M. A. (1995). Effects of Acid Washing on Stable Isotope Ratios of $\mathrm{C}$ and $\mathrm{N}$ in Penaeid Shrimp and Seagrass: Implications for Food-Web Studies Using Multiple Stable Isotopes. Limnology and Oceanography, 40(3), 622-625.

Cabanillas-Terán, N. (2009). Ecología y estatus trófico del erizo de mar Diadema antillarum (Philippi, 1845) en los fondos rocosos de las Islas Canarias (Gran Canaria, España). (Tesis doctoral). Universidad de las Palmas de Gran Canaria, España.

Cabanillas-Terán, N., Loor-Andrade, P., Rodríguez-Barreras, R., \& Cortés, J. (2016). Trophic ecology of sea urchins in coral-rocky reef systems, Ecuador. PeerJ, 4, e1578.

Caraveo-Patiño, J., \& Soto, L. (2005). Stable carbon isotope ratios for the gray whale (Eschrichtius robustus) in the breeding grounds of Baja California Sur, México. Hydrobiologia, 539, 99-107.

Clark, J. J., \& Wilcock, P. R. (2000). Effects of land-use change on channel morphology in northeastern Puerto Rico. GSA Bulletin, 112(12), 15.
Cloern, J. E. (2001). Our evolving conceptual model of the coastal eutrophication problem. Marine Ecology Progress Series, 210, 223-253.

Caut, S., Angulo, E., \& Courchamp, F. (2008). Discrimination factors $\left(\delta^{15} \mathrm{~N}\right.$ and $\left.\delta^{13} \mathrm{C}\right)$ in an omnivorous consumer: effect of diet isotopic ratio. Functional Ecology, 22, 255-263.

De Niro, M. J., \& Epstein, S. (1981). Influence of diet on the distribution of nitrogen isotopes in animals. Geochimica et Cosmochimica Acta, 45, 341-351.

Fry, B., \& Sherr, E. B. (1989). $\delta^{13} \mathrm{C}$ measurements as indicators of carbon flow in marine and freshwater ecosystems. Contribution to Marine Science, 27, $13-47$.

Hawkins, C. M. (1981). Efficiency of organic matter absorption by the tropical echinoid Diadema antillarum Philippi fed non-macrophytic algae. Journal of Experimental Marine Biology and Ecology, 49(2), 245-253.

Hendler, G., Miller, J. E., Pawson, D. L., \& Kier, P. M. (1995). Sea Stars, Sea Urchins, and Allies. Echinoderms of Florida and the Caribbean. Smithsonian Institution Press.

Hernández, J. C., Brito, A., García, N., Gil-Rodríguez, M. C., Herrera, G., Cruz-Reyes, A., \& Falcón, J.M. (2006). Spatial and seasonal variation of the gonad index of Diadema antillarum (Echinodermata: Echinoidea) in the Canary Islands. Scientia Marina, 70(4), 689-698.

Herrera-López, G., Cruz-Reyes, A., Hernández, J. C., García, N., González-Lorenzo, G., Gil-Rodríguez, M. C., Brito, A., \& Falcón, J. M. (2004). Alimentación y diversidad algal en la dieta del erizo Diadema antillarum en Tenerife. Revista Academia Canarias Ciencias, 15(3/4), 129-141.

Hobson, K. A., \& Sease, J. L. (1998). Stable isotope analyses of tooth annuli reveal temporal dietary records: an example using Steller sea lions. Marine Mammal Science, 14, 116-129.

Jackson, A. L., Inger, R., Parnell, A. C., \& Bearhop, S. (2011). Comparing isotopic niche widths among and within communities: SIBER - Stable Isotope Bayesian Ellipses in R. Journal of Animal Ecology, 80(3), 595-602.

Karlson, R. H. (1983). Disturbance and monopolization of a spatial resource by Zoanthus sociatus (Coelenterata, Anthozoa). Bulletin of Marine Science, 33, 118-131.

Keller, B. D. (1983). Coexistence of sea urchins in seagrass meadows: an experimental analysis of competition and predation. Ecology, 64(6), 1581-1598.

Klinger, T. S., Hsieh, H. L., Pangallo, R. A., Chen, C. P., \& Lawrence, J. M. (1986). The effect of temperature 
on feeding, digestion, and absorption of Lytechinus variegatus (Lamarck) (Echinodermata: Echinoidea). Physiological Zoology, 59(3)332-336.

Lawrence, J. M., Lawrence, A. L., \& Watts, S. A. (2013). Feeding, digestion, and digestibility of sea urchins. In J. M. Lawrence (Ed.), Sea Urchins, Biology and Ecology (Chapter 9, pp. 135-154). Amsterdam: Elsevier BV.

Lewis, J. B. (1964). Feeding and digestion in the tropical sea urchin Diadema antillarum Philippi. Canadian Journal of Zoology, 42(4), 549-557.

Littler, D. S., \& Littler, M. M. (2000). Caribbean reef plants. Washington, DC: Offshore Graphics Inc.

Mahon, R., \& Parker, C. (1999). Barbados sea eggs, past, present and future. Fisheries Division, Ministry of Agriculture and Rural Development, Barbados Fisheries Management Plan, Public Information Document.

McCutchan, J. H., Lewis, W. M., Kendall, C., \& McGrath, C. C. (2003). Variation in trophic shift for stable isotope ratios of carbon, nitrogen, and sulfur. Oikos, 102, 378-390.

McGlathery, K. J. (2001). Macroalgal blooms contribute to the decline of seagrass in nutrient-enriched coastal waters. Journal of Phycology, 37, 453-56.

McPherson, B. F. (1969). Studies on the biology of the tropical sea urchins Echinometra lucunter and Echinometra viridis. Bulletin of Marine Science, 19, 194-213.

Minagawa, M., \& Wada, E. (1984). Stepwise enrichment of ${ }^{15} \mathrm{~N}$ along food hains: further evidence and the relation between ${ }^{15} \mathrm{~N}$ and animal age. Geochimestry and Cosmochimestry Acta, 48, 1135-1140.

Nixon, S. W., Ammerman, J. W., Atkinson, L. P., Berounsky, V. M., Billen, G., Boicourt, W. C., \& Seitzinger, S. P. (1996). The fate of nitrogen and phosphorus at the land-sea margin of the North Atlantic Ocean. Biogeochemistry, 35, 141-180.

Parnell, A. C., Inger, R., Bearhop, S., \& Jackson, A. L. (2010). Source Partitioning Using Stable Isotopes: Coping with Too Much Variation. PLOS one, 5(3), $1-5$.

Parnell, A., \& Jackson, A. (2013). Siar: Stable Isotope Analysis in R. R package version 4.2. Downloaded from $\mathrm{http} / /$ CRAN.Rproject.org/package=siar

Peterson, B. J., \& Fry, B. (1987). Stable isotopes in ecosystem studies. Annual Review in Ecology and Systematic, 18, 293-320.

Peterson, B. J., Howarth, R. W., \& Garritt, R. H. (1985). Multiple stable isotopes used to trace the flow of organic matter flow in estuarine food webs. Science, 227, 1361-1363.

Pinnegar, J. K., \& Polunin, N. V. C. (2000). Contributions of stable-isotope data to elucidating food webs of Mediterranean rocky littoral fishes. Oecologia, 122(3), 399-409.

Phillips, D. (2012). Converting isotope values to diet composition: the use of mixing models. Journal of Mammalogy, 93(2), 342-352.

Post, D. M. (2002). Using stable isotopes to estimate trophic position models, methods, and assumptions. Ecology, 83(3), 703-718.

Prado, P. P., Alcoverro, T., \& Romero, J. (2010). Influence of nutrients in the feeding ecology of seagrass (Posidonia oceanica L.) consumers: a stable isotopes approach. Marine Biology, 157, 715-724.

Prado, P., Carmichael, R. H., Watts, S. A., Cebria, J., \& Heck, Jr. K. L. (2012). Diet-dependent $\delta 13 \mathrm{C}$ and $\delta 15 \mathrm{~N}$ fractionation among sea urchin Lytechinus variegatus tissues: implications for food web models. Marine Ecology Progress Series, 462, 175.

R Development Core Team. (2014). R: A language and environment for statistical computing. R Foundation for Statistical Computing, Vienna, Austria, ISBN 3-900051-07-0. http://www.R-project.org/

Rezende, C. E., Lacerda, L. D., Ovall, A. R. C., Silva, C. A. R., \& Martinelli, L. A. (1990). Nature of POC transport in a mangrove ecosystem: a carbon stable isotopic study. Estuarine, Coastal and Shelf Science, 30(6), 641-645.

Rodríguez, S. R. (2003). Consumption of drift kelp by intertidal populations of the sea urchin Tetrapygus niger on the central Chilean coast: possible consequences at different ecological levels. Marine Ecology Progress Series, 251, 141-151.

Rodríguez-Barreras, R., Cuevas, E., Cabanillas-Terán, N., \& Sabat, A. M. (2015). Potential omnivory of the sea urchin Diadema antillarum? Regional Studies in Marine Science, 2, 11-18.

Rodríguez-Barreras, R., Pérez, M. E., Williams, S. M., Mercado-Molina, A. E., \& Sabat, A. M. (2014). Higher population densities of the sea urchin Diadema antillarum linked to wave sheltered areas in north Puerto Rico Archipelago. Journal of the Marine Biological Association of the U.K., 94(8), 1661-1669.

Rotjan, R. D., \& Lewis, S. M. (2008). Impact of coral predators on tropical reefs. Marine Ecology Progress Series, 367, 73-91.

Semmens, B. X., Moore, J. W., \& Ward, E. J. (2009). Improving Bayesian isotope mixing models: a response to. Ecology Letters, 12, E6-E8. 
Serafy, D. K. (1979). Echinoids (Echinodermata: Echinoidea). Memoirs of the Hourglass Cruises, 5, 120.

Solomon, C. T., Carpenter, S. R., Clayton, M. K., Cole, J. J., Coloso, J. J., Pace, M. L., Vander Zanden, M. K., \& Weidel, B. C. (2011). Terrestrial, benthic, and pelagic resource use in lakes: results from a three-isotope Bayesian mixing model. Ecology, 92, 1115-1125.

Szepanski, M. M., Ben-David, M., \& Van Ballenberghe, V. (1999). Assessment of anadromous salmon resources in the diet of the Alexander Archipelago wolf using stable isotope analysis. Oecologia, 120, 327-335.

Tertschnig, W. P. (1989). Diel activity patterns and foraging dynamics of the sea urchin Tripneustes ventricosus in a tropical seagrass community and a reef environment (Virgin Islands). Marine Ecology, 10, 3-21.

Tewfik, A., Rasmussen, J., \& McCann, K. S. (2005). Anthropogenic enrichment alters a marine benthic food web. Ecology, 86(10), 2726-2736.

Tomas, F., Alvarez-Cascos, D., Turon, X., \& Romero, J. (2006). Differential element assimilation by sea grass urchin Paracentrotus lividus in seagrass beds: implications for trophic interactions. Marine Ecology Progress Series, 306, 125-131.

Trenzado, C. E., Hidalgo, F., Villanueva, D., Furné, M., Díaz-Casado, M. E., Merino, R., \& Sanz, A. (2012). Study of the enzymatic digestive profile in three species of Mediterranean sea urchins. Aquaculture, 344, 174-180.

U. S. G. S. (1996). Atlas of ground-water resources in Puerto Rico and the U.S. Virgin Islands. T. D. Veve and B. E. Taggart (Eds.). Water resources investigation report $(94-4198,151$ p.)

Van-Dover, C. L., Grassle, J. F., Fry, B., Garrit, R. H., \& Starczak, V. R. (1992). Stable isotopes evidence for entry of sewage-derived organic material into a deepsea food web. Organic Geochemistry, 27, 103-113.
Vander-Zanden, M. J., \& Rasmussen, J. B. (2001). Variation in $\delta^{15} \mathrm{~N}$ and $\delta^{13} \mathrm{C}$ trophic fractionation: Implications for aquatic food web studies. Limnology and Oceanography, 46(8), 2061-2066.

Vanderklift, M. A., \& Ponsard, S. (2003). Sources of variation in consumer-diet $\delta^{15} \mathrm{~N}$ enrichment: a metaanalysis. Oecologia, 136, 169-182.

Vanderklift, M. A., Kendrick, G. A., \& Smith, A. J. (2006). Differences in trophic position among sympatric sea urchin species. Estuarine, Coastal and Shelf Science, 66, 291-297.

Villinski, J. C., Hayes, J. M., Villinski, J. T., Brassell, S. C., \& Raff, R. A. (2004). Carbon-isotopic shifts associated with heterotrophy and biosynthetic pathways in direct and indirect-developing sea urchins. Marine Ecology Progress Series, 275, 139-151.

Wangensteen, O. S., Turón, X., García-Cisneros, A., Recasens, M., Romero, J., \& Palacín, C. (2011). A wolf in sheep's clothing: carnivory in dominant sea urchins in the Mediterranean. Marine Ecology Progress Series, 441, 117-128.

Wing, S. R., McLeod, R. J., Clark, K. L., \& Frew, R. D. (2008). Plasticity in the diet of two echinoderm species across an ecotone: microbial recycling of forest litter and bottom-up forcing of populations structure. Marine Pollution Bulletin, 360, 115-123.

Wolf, N., Scott, A., \& Martínez del Río, C. (2009). Nutritional ecology: Ten years of experimental animal isotopic ecology. Functional Ecology, 23, 17-26.

Zar, J. H. (2010). Biostatistical analysis (5th Edition). Upper Saddle River, Prentice Hall, Upper Saddle River, New Jersey.

Zieman, J. C., Macko, S. A., \& Mills, A. L. (1984). Role of seagrasses and mangroves in estuarine food webs: temporal and spatial changes in stable isotope composition and amino acid content during decomposition. Bulletin of Marine Science, 35(3), 380-392. 